\title{
Hydrological hazard estimation for the municipality of Yautepec de Zaragoza, Morelos, Mexico
}

\author{
Emmanuel Zúñiga ${ }^{1, *}$ (D) and David A. Novelo-Casanova ${ }^{2}$ \\ 1 CONACYT - Instituto de Geografía, Universidad Nacional Autónoma de México, Circuito de la \\ Investigación Científica, Ciudad Universitaria 04510, Mexico \\ 2 Departamento de Sismología, Instituto de Geofísica, Universidad Nacional Autónoma de México, \\ Circuito de la Investigación Científica, Ciudad Universitaria 04510, Mexico \\ * Correspondence: ezuniga@igg.unam.mx
}

Received: 26 June 2019; Accepted: 23 August 2019; Published: 27 August 2019

\begin{abstract}
The hydrological hazard for the municipality of Yautepec de Zaragoza, State of Morelos, Mexico, is evaluated considering the overflow process of the rivers located in the Yautepec sub-basin. Different scenarios of hydrological hazard were generated to identify those areas with high flood potential using hydraulic modeling for three return periods (Rp) of 50, 100 and 500 years based on statistical analysis of the maximum annual discharge of the Yautepec hydrometric station. We used the Hec-Ras software and geographic information systems (GIS) to model the different flood scenarios. Our results indicate that $10 \%\left(1.5 \mathrm{~km}^{2}\right)$ of the total urban area of the municipality will be flooded for a return period of 50 years. About $12 \%\left(1.8 \mathrm{~km}^{2}\right)$ of the territory will be affected by flood for a $\mathrm{Rp}$ of 100 years. For a Rp of 500 years, approximately $13.5 \%\left(2.1 \mathrm{~km}^{2}\right)$ of the municipality's area will be flooded. Spatially, the central and southern regions of the municipality will be affected by flood heights greater than $1 \mathrm{~m}$ for $\mathrm{Rp}$ of 100 and 500 years. The northern zone will have heights of less than $0.50 \mathrm{~m}$ for Rp of 50 years. Our results can be used as a tool to prevent and reduce the impact of future floods in the municipality of Yautepec de Zaragoza.
\end{abstract}

Keywords: Hydrological hazard; flood; hydraulic modeling; return periods; overflow; Yautepec de Zaragoza; Mexico

\section{Introduction}

Worldwide, disasters caused by floods generate enormous social, economic and environmental impact. Because of their frequency, there is damage to infrastructure and roads in urban areas that reduce the natural dynamics of cities and their activities [1-5]. In general, the recurrence of hydrological hazard events due to river overflows causes greater economic and social impact in urban than in suburban and rural areas. This is mainly because, commonly, in cities of third world countries, the level of vulnerability and risk increase as a consequence of the process of watersheds' deterioration and poor management of the territory. On the other hand, in non-urban watersheds, damage is limited to small areas with minimal exposed infrastructure [6-9].

The process of urbanization of hydrological basins and the transformation of natural soils by less permeable coverings such as agricultural and urban soils, has modified the natural hydrological cycle of the basins and, consequently, loss of capacity to regulate the runoff generated by even low intensity and short duration rains [10-16]. These conditions increase the hydrological hazard due to overflowing of rivers because of the loss of hydraulic capacity of the channels to drive large volumes of runoff [17-19]. In addition, it increases the risk of flooding for the exposed population [20-22].

Data from the Mexican National Center for Disaster Prevention [23] and the Disaster Inventory System for Latin America [24] report that approximately 50\% of the disasters occurred in Mexico 
during 1970-2010, are the result of urban floods. Recently, it has been established that about $88 \%$ of the economic losses caused by disasters in Mexico during the period 2000 - 2015 are related to hydrometeorological events.

Located in the central part of the state of Morelos, the municipality of Yautepec de Zaragoza is frequently affected by the overflow of the Yautepec, Apanquetzalco, and Oacalco rivers that run through the municipality from north to south. According to data from the General Directorate of Civil Protection of the Yautepec municipality (DGCPY) [25] and reports from the local population, 20 disasters were registered in this locality due to the overflow of these rivers during the period 1965-2015.

In the town of Yautepec, there are three metallic plaques that indicate the height of the floods that occurred during last years. The floods of $1985(1.60 \mathrm{~m}), 1998(1.95 \mathrm{~m})$ and $2003(2.10 \mathrm{~m})$ caused economic losses estimated at $\$ 15,000,000.00$ Mexican pesos (approximately $\$ 754,000.00$ USD) due to severe damage to the local infrastructure, in addition to the loss of human lives reported during the year 1998.

Estrada [26] highlights the importance of reducing the runoff generated in the upper Yautepec River basin as a result of the loss of the local soil's infiltration capacity by degradation processes. The author establishes the importance of the use of hydraulic infrastructure as element to reduce the increase in runoff (33\%) observed during the period 1990-2000. This measure will avoid future floods due to overflow of the local rivers. Additionally, Zúñiga [27] considers that the loss of hydraulic capacity of the channels reduces their ability to control and conduct runoff naturally, increasing the level of hydrological hazard and risk.

At present, there is a large number of specialized computer programs to assess the water flow behavior in rivers and channels [28-30]. In this work we use the Hec-Ras model to identify the potential flood zones due to overflowing the Yautepec, Apanquetzalco and Oacalco rivers in the urban area of the Yautepec municipality of Zaragoza. Hec-Ras is one of the most used tool to model river's flow and delimit floodplains. Due to its capacity to process and analyze hydrological and hydraulic parameters, the Hec-Ras model is used to forecast floods in urban areas. Additionally, this tool developed by the Hydraulic Engineering Center (Hec) of the US Army Corps of Engineers allows to incorporate geometric information generated from low-resolution terrain models. Also, the calculation speed is high allowing performing simulations of very large zones in short times. Besides, the combined use of the Hec-Ras model and geographical information systems (GIS) is the perfect tool to generate scenarios of hydrological hazard and flood risk for urban areas [31-39]. Hydraulic modeling to generate hydrological hazard scenarios due to river overflows in urban areas is widely used [40-43].

The main purpose of this work is to generate hydrological hazard scenarios for the urban area of the municipality of Yautepec de Zaragoza considering the hydraulic modeling of the Yautepec sub-basin's rivers and statistical analysis of annual maximums discharges for return periods (Rp) of 50, 100 and 500 years. We identify those local urban areas exposed to flooding. In addition, our results highlight the importance of assessing flood hazard and risk due to river overflowing in urban areas.

\section{Study Area}

The sub-basin of the study area has an area of $148 \mathrm{~km}^{2}$ and it is located in the central-northern side of the municipality of Yautepec de Zaragoza (Figure 1). This sub-basin is part of the Yautepec river basin $\left(1,543 \mathrm{~km}^{2}\right)$ that belongs to the local Grande Amacuzac river basin. The study area is within the hydrological region No. 18 Río Balsas according to the Mexican classification of hydrological zones [44]. 


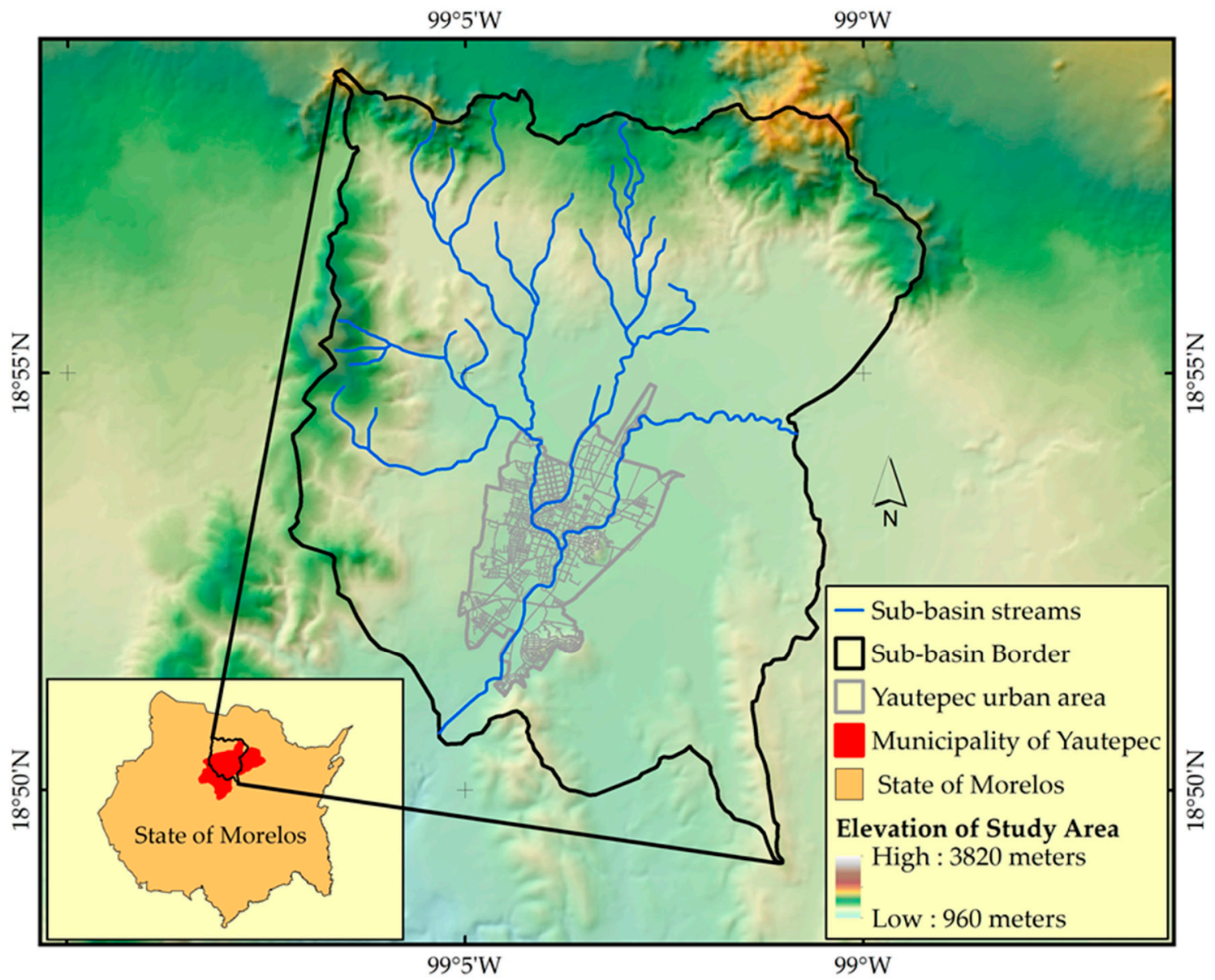

Figure 1. Location of the Yautepec River Basin in the Yautepec Municipality, State of Morelos, Mexico.

According to the hydrological classification of Vide [45], the hydrological conditions of the local rivers are as follows: (i) The Yautepec River is an old plain river with gentle slope and presence of meanders with deposit of fine material (clay - sandy); and (ii) the Apanquetzalco and Oacalco rivers are mature-old rivers (transition) of irregular relief with medium texture material (redzina) of sandy soil (feozem calcaric) and intermediate permeability [27].

\section{Materials and Methods}

\subsection{Statistical Analysis}

To analyze the annual maximum discharge, we used 57-year historical data (1949-2006) recorded in the Yautepec station $\left(18^{\circ} 89^{\prime} \mathrm{N}, 99^{\circ} 05^{\prime} \mathrm{W}\right.$ (National Data Bank of Surface Waters, [BANDAS] of the Mexican National Water Commission [46].

Because of their low hydrological dynamics, the Apanquetzalco and Oacalco rivers are not regularly monitored. For this reason, the discharge from the channels was estimated from the areas of runoff contribution and the hydrological similarity with the Yautepec River.

The statistical analysis for the annual maximum discharge was performed using the methodology proposed by Escalante and Reyes [47]. This methodology allows analyzing the frequency of extreme events by relating its magnitude $\hat{\mathbf{Q}}_{\mathrm{T}}$ with its return period. According to Rao and Hamed [48] and Chow [49], this type of analysis is widely used in the field of hydrology to determine the frequency of floods.

To verify the homogeneity and robustness of the annual maximum discharge we used the Cramer-type homogeneity test $t_{w}$ [47], considering three blocks with different data sets. The first block contains the total sample size $n_{j}$. The second and third blocks of size $\mathrm{w}=60$ and $\mathrm{w}=30$ have $60 \%$ and 
$30 \%$ of $n_{j}$, respectively. The level of homogeneity for the series $\mathrm{j}$ for $\mathrm{i}=1,2, \ldots \boldsymbol{n}_{\boldsymbol{j}}$, was determined by comparing the value of $\bar{Q}^{j}$ (1) of the total record with the blocks $\bar{Q}_{60}^{j}$ (2) and $\bar{Q}_{30}^{j}$ (3), and by using equation (4):

$$
\begin{gathered}
\bar{Q}^{j}=\sum_{j=1}^{n_{j}} \frac{Q_{i}^{j}}{n_{j}} \\
\overline{\mathbf{Q}}_{60}^{\mathrm{j}}=\sum_{\mathbf{k}=1}^{\mathrm{n}_{60}} \frac{\mathbf{Q}_{\mathbf{k}}^{\mathrm{j}}}{\mathrm{n}_{60}} \\
\overline{\mathbf{Q}}_{30}^{\mathrm{j}}=\sum_{\mathbf{k}=1}^{\mathrm{n}_{30}} \frac{\mathbf{Q}_{\mathbf{k}}^{\mathrm{j}}}{\mathrm{n}_{30}} \\
t_{w}\left\{\frac{n_{w}\left(n_{j}-2\right)}{n_{j}-n_{w}\left[1+\left(\tau_{w}^{j}\right)^{2}\right]}\right\}^{\frac{1}{2}}\left|\tau_{w}^{j}\right| \text { for : } 60 \text { and } 30
\end{gathered}
$$

where:

$n_{w}=$ Blocks of size $\mathrm{w}=60$ and $\mathrm{w}=30$

$n_{j}=$ Total sample size

$\tau_{w}^{j}=\bar{Q}_{w 60 ; w 30}^{j}-\bar{Q}^{j} / S$

$\mathrm{S}=$ Standard deviation of total sample size

The Anderson independence test (5) [50] was applied to determine the randomness of the sample variables and their domain within the confidence limits (6). The coefficient of serial autocorrelation $\mathbf{r}_{\mathbf{k}}^{\mathbf{j}}$ was established for different periods of delay and for a single record $j=1$ [47]:

$$
\mathrm{r}_{\mathrm{k}}^{\mathrm{j}} \frac{\sum_{\mathrm{i}=1}^{\mathrm{n}_{\mathrm{j}-\mathrm{k}}}\left(\mathbf{X}_{\mathrm{i}}^{\mathrm{j}}-\overline{\mathbf{X}^{\mathrm{j}}}\right)\left(\mathbf{X}_{\mathbf{i}+\mathbf{k}}^{\mathrm{j}}-\overline{\mathbf{X}^{\mathrm{j}}}\right)}{\sum_{\mathrm{i}=}^{\mathbf{n}_{\mathrm{j}}}\left(\mathbf{X}_{\mathrm{i}}^{\mathrm{j}}-\overline{\mathbf{X}^{\mathrm{j}}}\right)^{2}}
$$

where:

$\mathbf{j}=$ Sampled data.

$\mathbf{k}=$ Delay time.

$\mathbf{n}_{\mathbf{j}}=$ Number of data.

$\overline{\mathbf{X}^{\mathbf{j}}}=$ Sample mean of $\mathbf{j}$.

The confidence limits for $\mathbf{r}_{\mathbf{k}}^{\mathbf{j}}$ were obtained from the following equation [47]:

$$
\mathrm{r}_{\mathbf{k}}^{\mathrm{j}}(95 \%)=\frac{1- \pm 1.96 \sqrt{\mathbf{n}_{\mathrm{j}}-\mathbf{k}-1}}{\mathbf{n}_{\mathrm{j}}-\mathbf{k}}
$$

The return period for maximum discharge of certain magnitude $X$ was determined using the empirical Weibull type distribution [47]:

$$
\mathbf{T}=\frac{\mathbf{n}+\mathbf{1}}{\mathbf{m}}
$$

where:

$\mathbf{n}=$ Sample size

$\mathbf{m}=$ Registration order number considering a determined return period . 
The exceedance probability was obtained using [51]:

$$
\mathbf{P}(\mathbf{X} \leq \mathbf{x})=\mathbf{1}-\frac{\mathbf{1}}{\mathbf{T}}
$$

All calculations for the Yautepec station data series where performed for Rp of 50, 100 and 500 years. As part of the frequency analysis, the following sample statistics were obtained: Asymmetry coefficient, kurtosis coefficient, variation coefficient, standard deviation, and arithmetic mean.

The distribution of probabilities of annual maximum discharge was determined from the following probability distributions of data series: Normal, log normal with two parameters, log normal with three parameters, exponential with parameter B, gamma with two parameters, gamma with three parameters, log Pearson type III, extreme values I (Gumbel), and general extreme values (GVE).

From the calculation of the standard error (SE), the best distribution of probabilities was determined for the series of data analyzed considering the following equation [47]:

$$
E E=\left[\frac{\sum_{i=1}^{\mathbf{n}_{j}}\left(Q_{T}^{j}-Q_{T}^{j}\right)^{2}}{\mathbf{n}_{j}-\mathbf{m p}}\right]
$$

where:

$Q_{T}^{j}$ includes the $Q_{i}^{j}$ events ordered from the highest to the lowest values with an assigned Rp of $\mathbf{T}=\frac{\mathbf{n}+\mathbf{1}}{\mathbf{m}}$ and a probability of non-exceedance given by [47]:

$$
\mathbf{P}(\mathbf{X} \leq \mathbf{x})=\mathbf{1}-\frac{\mathbf{1}}{\mathbf{T}}
$$

where:

$\mathbf{n}_{\mathbf{j}}=$ Length in years of the analyzed record .

$M=$ Registration order number.

$\mathbf{Q}_{\mathbf{T}}^{\mathbf{j}}=$ Events estimated with a certain probability distribution for $R p$ assigned to the ordered sample $\mathbf{Q}_{\mathbf{i}}^{\mathbf{j}}$. $M p=$ Number of parameters of the adjusted distribution.

\subsection{Hydraulic Flow Model for the Yautepec River Sub-Basin}

The geometric parameters and hydrological characteristics of the Yautepec, Apanquetzalco, and Oacalco rivers were obtained by processing topographic information [52-55]. The hydrological hazard scenarios were modeled following the procedures described in Figure 2. For the hydraulic flow modeling we considered the following hydraulic parameters for simulation: (i) The Manning number (roughness coefficient) of 0.035 [49] for the channel and 0.015 [49,56] for the urban area; (ii) critical depth boundary conditions and a mixed flow regime were used for simulations $[57,58]$ due to changes in slope and size of channel sections. To calibrate the hydraulic model, the estimated flood height for the hydraulic model of the flood events that occurred in 1985, 1998 and 2003 was compared with the historical records of these same events. The observed difference in flood height was of only $35 \mathrm{~cm}$. Thus, we consider that our results and analysis are valid.

The maximum annual discharge values for $\mathrm{Rp}$ of 50, 100, and 500 years [57] were integrated to determine the overflow zones for the urban area of the municipality. 


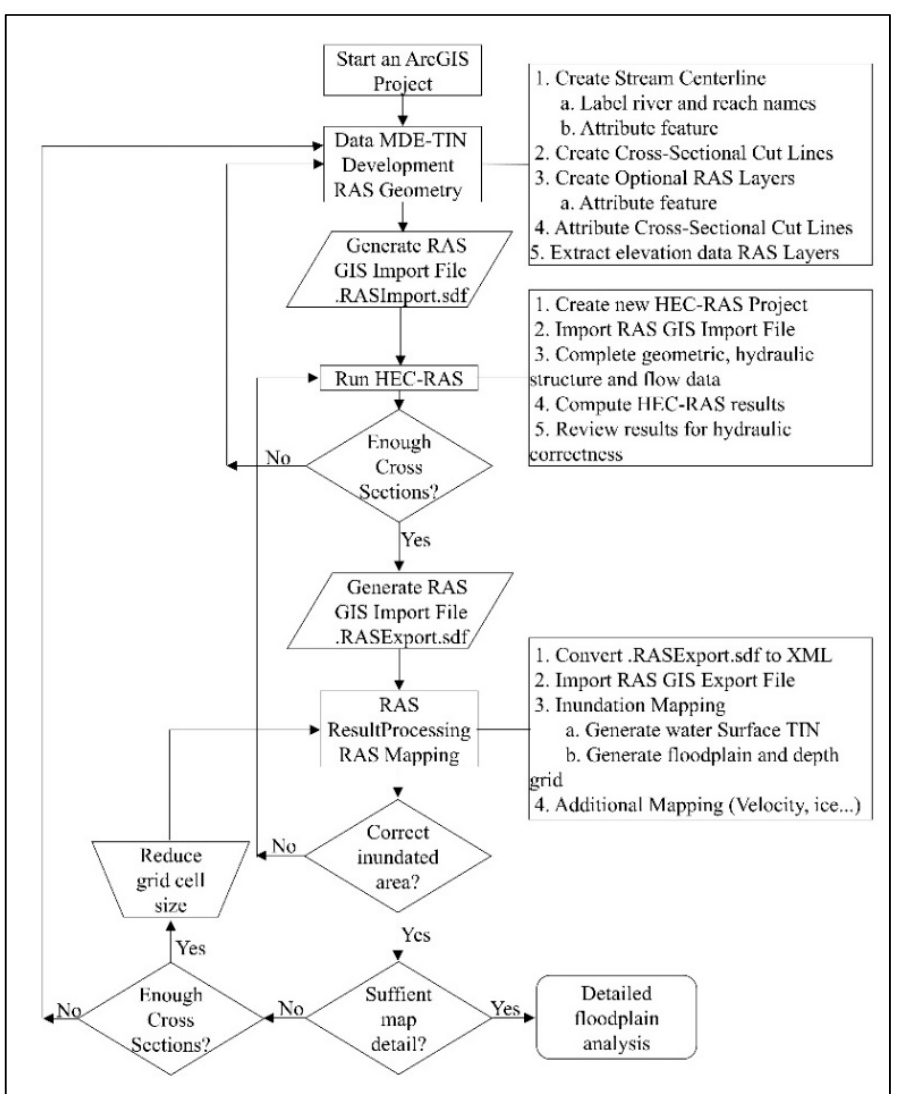

Figure 2. Hydraulic Engineering Center (HEC) GeoRAS-GIS and HEC-RAS flowchart to determine the geometrical parameters and the flood areas from hydraulic modeling.

\section{Results}

\subsection{Statistical Analysis}

In agreement with the statistical test of Cramer, it was determined that the homogeneity of the data for each block is fulfilled for $t_{30}$ and partially for $t_{60}$ :

$$
\left|t_{60}\right| \leq t_{v, 1-\alpha / 2} y\left|t_{30}\right| \leq t_{v, 1-\alpha / 2}
$$

where:

$v=(\mathrm{w}=60+\mathrm{w}=30)-2$

$\alpha=0.05$

$t_{v}=$ Student's t-distribution quantiles

With a level of significance of $\alpha=0.05$ and $v=49$ degrees of freedom $t_{49,97.5}=2.021$ (11) [47], it is considered that the series are inhomogeneous because the absolute values of $t_{60}|2.22|$ and $t_{30}|1.98|$ calculated with Cramer (4) are larger and less than 2.021, respectively. This comparison establishes that the series of data shows an independent and random behavior within the confidence limits shown in the independence correlogram (Figure 3). 


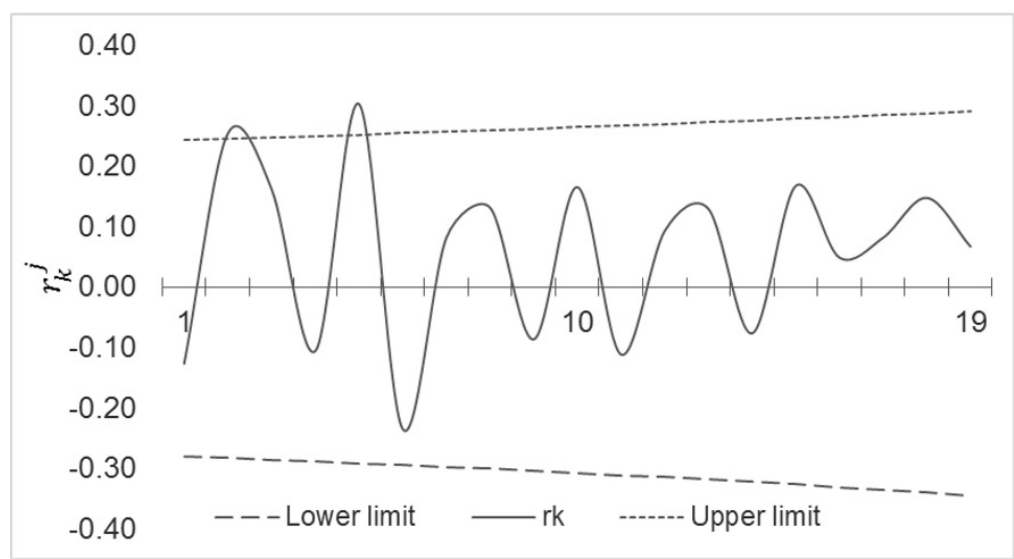

Figure 3. Correlation diagram of the data series.

The sample statistics used to analyze the frequency of the annual maximum discharge are:

Asymmetry coefficient $\mathrm{g}=0.62$

Coefficient of kurtosis $\mathrm{k}=3.34$

Variation coefficient $\mathrm{CV}=0.50$

Standard deviation $S=64.42$

Average $\bar{X}=128.74$

According to the distribution function of probabilities used, the best fit with minimum error for the reduced general function of extreme values (GEV) were estimated from the moments L (M-L) $[59,60]$ (Table 1). According to Ferrer [61], the GEV function is the statistics most commonly used in the specialized literature to analyze flows. Other authors $[59,62]$ consider the M-L estimator as the best hydrological adjustment:

$$
y=-\frac{1}{\beta} \operatorname{In}\left(1-\left(\frac{x-v}{\alpha}\right) \beta\right)^{\frac{1}{\beta}}
$$

where:

$v=$ Location

$\beta=$ Shape

$\alpha=$ Scale $>0$.

The estimator for Moments L (M-L) is calculated using the following equation:

$$
\hat{Q}_{T}=\hat{v}+\frac{\hat{\alpha}}{\hat{\beta}}\left\{1-[-\operatorname{In}(1-1 / T)]^{\hat{\beta}}\right\}
$$

Table 1. Distribution functions with minimum adjustment error*.

\begin{tabular}{cccccc}
\hline Distribution/Parameter & M & M-ML & M-L & ML & HP \\
\hline Normal & & 11.41 & 11.41 & & \\
Log Normal with two parameters & & 16.23 & & & \\
Log Normal with three parameters & 7.95 & & & & \\
Exponential with parameter $\beta$ & 16.91 & 55.53 & & 44.72 & \\
Gamma with two parameters & 8.46 & & 7.71 & 7.58 & \\
Gamma with three parameters & 7.83 & & & & 7.72 \\
Log Pearson typo III & 8.32 & & & & \\
Extreme Values I (Gumbel) & 8.56 & & 7.52 & 7.29 & \\
General extreme values (GEV) & & & 7.02 & &
\end{tabular}

*M: Moment; M-ML: Moment and maximum likelihood; M-L: Moment L; ML: Maximum likelihood; HP: Heavy probability. 
Considering the GEV distribution, the maximum discharge for the Apanquetzalco and Oacalco rivers were obtained by relating areas of runoff contribution $(35 \%$ and $40 \%)$ with the area of the Yautepec River (Table 2).

Table 2. Maximum discharge probability for different return periods (Rp).

\begin{tabular}{cccc}
\hline River/ $\hat{Q}_{\boldsymbol{T}}\left(\mathbf{m}^{\mathbf{3}} / \mathbf{s}\right)$ & $\mathbf{R p} \mathbf{5 0}$ years & $\mathbf{R p ~} \mathbf{1 0 0}$ years & $\mathbf{R p} \mathbf{5 0 0}$ years \\
\hline Yautepec & 288 & 316 & 373 \\
Apanquetzalco & 100.8 & 110.6 & 130.5 \\
Oacalco & 115.2 & 126.4 & 149.2 \\
\hline
\end{tabular}

\subsection{Hydraulic Modeling}

$R p$ of 50,100, and 500 years considered to generate the hydraulic model and the overflow process of the Yautepec, Oacalco and Apanquetzalco rivers are commonly used in hydrology to evaluate hydrological hazard and flood risk. Authors such as Campos [63] and Herrero et al. [64] consider that values for $R p 500$ years establish the zone of maximum floods and $R p 100$ years define the area of free circulation of floods "via intense drainage". For Wolfgang [65], Merz [66] and the Federal Emergency Management Agency of the United States [67], areas with high flood risk are determined from values of $R p 50$ years.

The spatial distribution of the hydrological hazard by overflow of the Yautepec, Oacalco, and Apanquetzalco rivers for $R p$ of 50, 100, and 500 years is displayed in Figures 4-6, respectively. The level of hazard was classified considering the flood height and possible impact to the local infrastructure and population (Table 3):

- High: Flood height $>1 \mathrm{~m}$. Expected losses in infrastructure and population. They are infrequent events.

- Moderate: Flood height $>50 \mathrm{~cm}$ and $<1 \mathrm{~m}$. Moderate damage and some losses in infrastructure with low impact to local people. They are events of moderate frequency.

- Low: Flood height $<50 \mathrm{~cm}$. Minimal impact to infrastructure and population. They are high frequency events.

Table 3. Hydrological hazard levels for different return periods (Rp)*

\begin{tabular}{|c|c|c|c|c|}
\hline \multicolumn{2}{|c|}{ Flood Level (m). } & \multicolumn{3}{|c|}{ Hazard Level. } \\
\hline $\mathrm{H}$ & $>1.00$ & $\mathrm{H}$ & $\mathrm{H}$ & $\mathrm{H}$ \\
\hline M & $0.51-1.00$ & $\mathrm{H}$ & M & $\mathrm{L}$ \\
\hline \multirow[t]{2}{*}{$\mathrm{L}$} & $0.0-0.50$ & M & $\mathrm{L}$ & $\mathrm{L}$ \\
\hline & & $\begin{array}{c}\mathrm{Rp} \leq 50 \\
\mathrm{H}\end{array}$ & $\begin{array}{c}50<\mathrm{Rp} \leq 100 \\
\mathrm{M} \\
\text { Frequency }(\mathrm{ye}\end{array}$ & $\begin{array}{l}100<\mathrm{Rp} \leq 500 \\
\mathrm{~L} \\
\mathrm{rs})\end{array}$ \\
\hline
\end{tabular}

${ }^{*}$ H: High (H); M: Moderate; (M); L: Low.

Considering the different flood scenarios for the urban area of the municipality of Yautepec (15.52 $\mathrm{km}^{2}$ ) (Figures 4-6), we find the following levels of hydrological hazard for the urban area affected by the overflow of the Yautepec Oacalco and Apanquetzalco rivers:

- For $R p 50$ years, $10 \%\left(1.5 \mathrm{~km}^{2}\right)$ of the total community area will be flooded: Of this flooded area, $65 \%$ will be covered with a water level $\leq 50 \mathrm{~cm} ; 15.5 \%$ between $0.50 \mathrm{~cm}$ and $1.0 \mathrm{~m}$; and $19.5 \%>$ $1.0 \mathrm{~m}$.

- For $R p 100$ years, $12 \%\left(1.8 \mathrm{~km}^{2}\right)$ of the total community area will be flooded: of this flooded area, $62 \%$ will have a water level $\leq 50 \mathrm{~cm} ; 18.5 \%$ from $0.50 \mathrm{~cm}$ to $1.0 \mathrm{~m}$ and $19.5 \%>1.0 \mathrm{~m}$. 
- For $R p 500$ years, $13.5 \%\left(2.1 \mathrm{~km}^{2}\right)$ of the total community area will be flooded: of this flooded area, $59 \%$ will reach a water level $\leq 50 \mathrm{~cm} ; 18.4 \%$ between of $0.50 \mathrm{~cm}$ to 1.0 and $22.6 \%>1.0 \mathrm{~m}$.

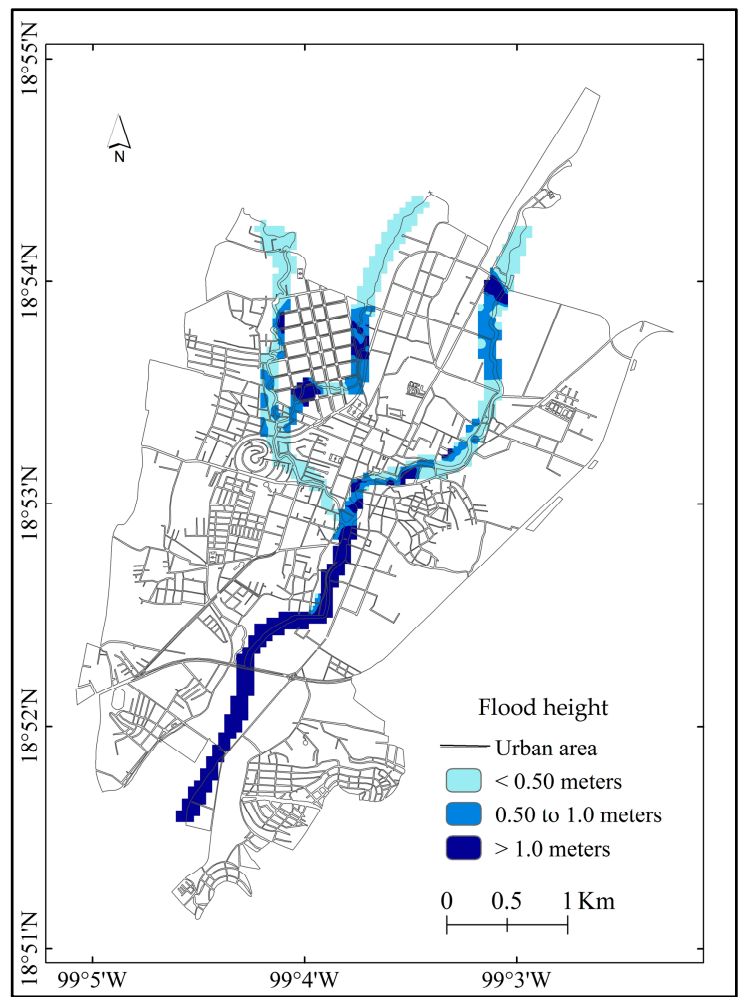

Figure 4. Hydrological hazard map for $\mathrm{Rp}=50$ years due to overflow of the Yautepec, Oacalco, and Apanquetzalco rivers.

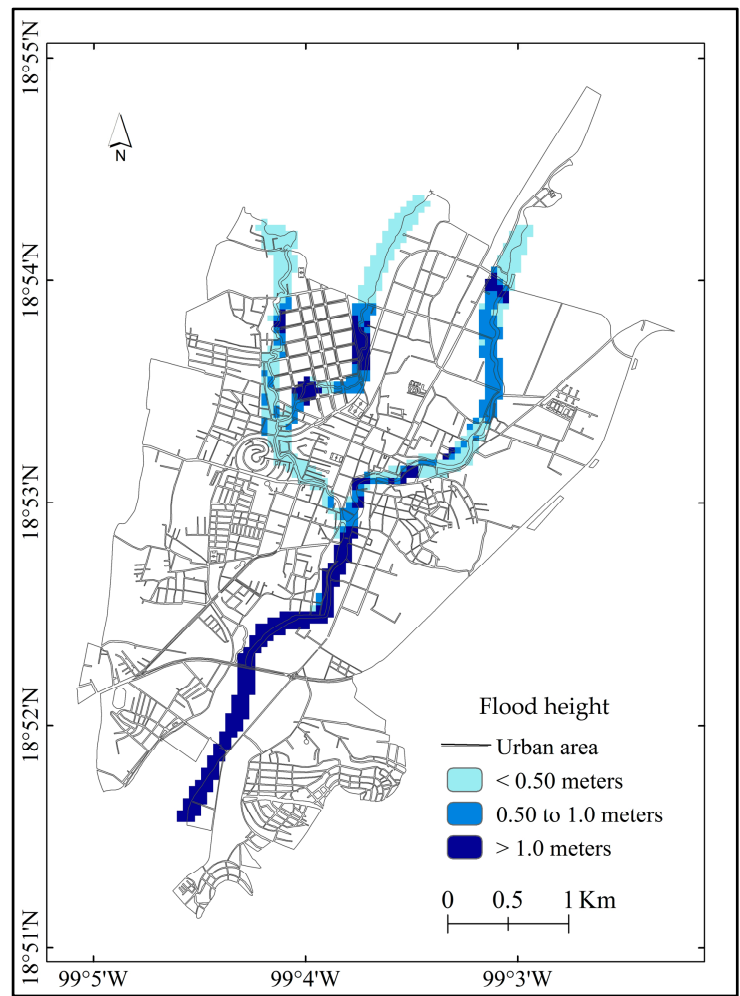

Figure 5. Hydrological hazard map for $\mathrm{Rp}=100$ years due to overflow of the Yautepec, Oacalco and Apanquetzalco rivers. 


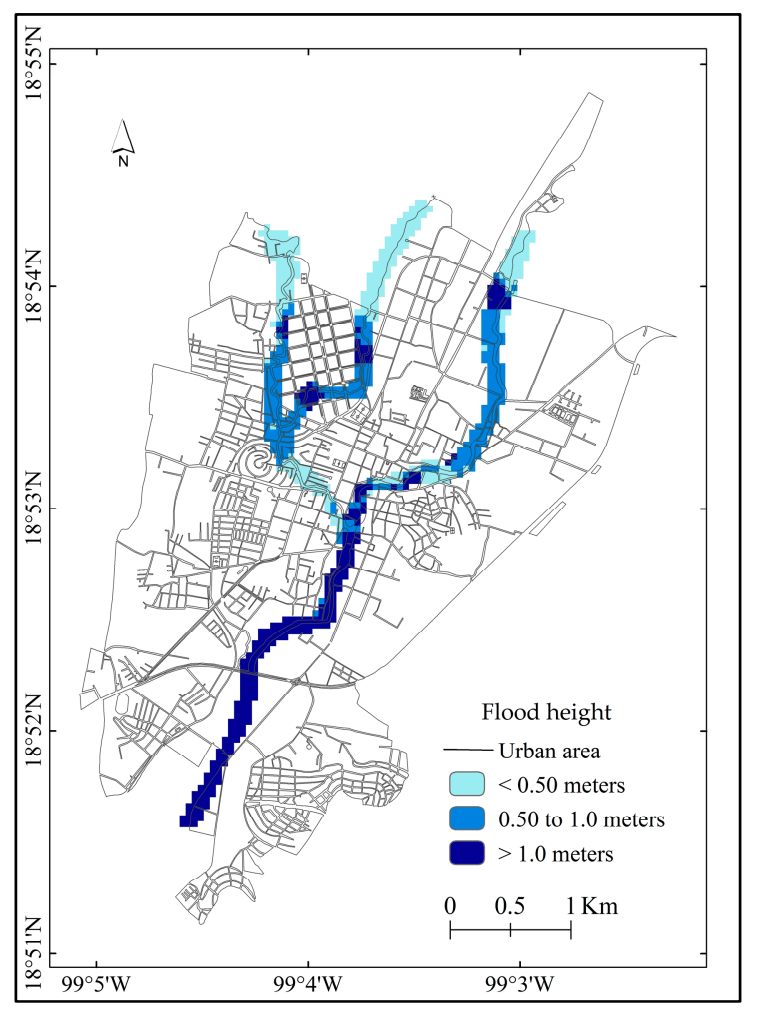

Figure 6. Hydrological hazard map for $\mathrm{Rp}=500$ years due to overflow of the Yautepec, Oacalco and Apanquetzalco rivers.

\section{Discussion}

Our results describe the spatial distribution of the hydrological hazard for the municipality of Yautepec and identify those critical zones of the local rivers' channel with high levels of flood for Rp of 50,100 , and 500 years. Considering the number of blocks in the exposed flood areas, the number of houses that could be damaged by flooding is approximately 2,375 with an estimated 11,875 habitants. Zúniga [27] estimated that each block of the Yautepec community has 25 households with an average of about five habitants. Although our findings can be used as a tool to manage flood risk and reduce future flood impacts in Yautepec, it is necessary to improve the hydrological hazard scenarios by incorporating digital elevation models (DEM) with higher spatial resolution in the simulation of flow. Additionally, it is important to update and incorporate information about the structural and social vulnerability for the different scenarios with the purpose of generating dynamic flood risk maps.

Due to its geographical location, various urban areas in Mexico are continually exposed to floods. This is because of the high frequency of heavy rains and the vulnerability of the hydrological basins due to changes in land cover [14]. The current technological development and the use of hydraulic modeling to generate hydrological hazard scenarios have allowed to define those areas with high flood risk for different cities in Mexico [40-43,68,69]. In this work, the Hec-Ras software was used to identify zones in the urban area of the municipality of Yautepec that will be affected in the future by river overflow for different return periods.

The methodology developed here can be applied to other regions in Mexico that have suffered the impact of floods in the past. Hydrological hazard and risk maps can be used as a tool for disaster management and land regulations plans.

\section{Conclusions}

Statistical analysis of annual maximum discharges with hydraulic simulation to generate scenarios of hydrological hazard for different $\mathrm{Rp}$ of 50, 100 and 500 years, allowed us to map and identify those 
zones with high probability of flooding by overflow of the Yautepec, Apanquetzalco, and Oacalco rivers in the urban area of the Yautepec municipality of Zaragoza, Morelos, Mexico.

The hydrological hazard levels found indicate that about 10\% $\left(1.5 \mathrm{~km}^{2}\right), 12 \%\left(1.8 \mathrm{~km}^{2}\right)$ and $13.5 \%$ $\left(2.1 \mathrm{~km}^{2}\right)$ of the urban area $(15.52 \mathrm{~km} 2)$ of the studied municipality could be affected by flood heights below $50 \mathrm{~cm}$, between $50 \mathrm{~cm}$ and $1.0 \mathrm{~m}$, and more than $1.0 \mathrm{~m}$ for Rp of 50, 100 and 500 years, respectively.

The use of hydraulic modeling as a tool to map hydrological hazard scenarios, allows us to identify those zones with high probability of flooding. We believe that our results can be used as a tool to prevent and reduce the impact of future floods in the municipality of Yautepec de Zaragoza. Also, our findings can be useful for land use regulations in the studied area.

Author Contributions: E.Z., D.A.N.-C. designed the research concept, methodology, and investigation. E.Z. performed the data processing and selected the tools for modeling. E.Z., D.A.N.-C.; edition and review of the manuscript.

Funding: This research received no external funding.

Acknowledgments: This study was supported by the National Laboratory of Earth Observation (LANOT-2018-295081) providing computing infrastructure for data processing. We thank Gustavo Vazquez Cruz for his support in scientific computation.

Conflicts of Interest: The authors declare no conflicts of interest.

\section{References}

1. Jonkman, S.N. Global perspectives on loss of human life caused by floods. Nat. Hazards 2005, 34, 151-175. [CrossRef]

2. Ahmad, B.; Zakir, H. Hydrological modelling and flood hazard mapping of Nullah Lai. Proc. Pak. Acad. Sci. 2010, 47, 215-226.

3. Kourgialas, N.N.; Karatzas, G.P. Flood management and a GIS modelling method to assess flood-hazard areas-A case study. Hydrolog. Sci. J. 2011, 56, 212-225. [CrossRef]

4. Johnson, C.; Blackburn, S. Making Cities Resilient Report 2012: My City Getting Ready! A Global Snapshot of How Local Governments Reduce Disaster Risk; The United Nations International Strategy for Disaster Reduction: Geneva, Switzerland, 2012; ISBN 978-92-1-132036-7.

5. Munich, R.E.; Kron, W.; Schuck, A. Topics Geo: Natural Catastrophes 2013: Analyses, Assessments, Positions; Munchener Ruckversicherungs-Gesellschaf: Munich, Germany, 2014; Available online: https://www.munichre.com/site/corporate/get/documents_E1043212252/mr/assetpool. shared/Documents/5_Touch/_Publications/302-08121_en.pdf (accessed on 1 January 2019).

6. Konrad, C.P. Effects of Urban Development on Floods 2003. Available online: https://pubs.usgs.gov/fs/fs07603/ (accessed on 1 December 2018).

7. Douglas, I.; Kobold, M.; Lawson, N. Characterization of Urban Streams and Flooding. Advances in Urban Flood Management; CRC Press: London, UK, 2007; pp. 41-70. Available online: https://doi.org/10.1201/ 9780203945988 (accessed on 1 December 2018).

8. Aragón-Durand, F. Urbanization and Flood Vulnerability in the peri-urban interface of Mexico City. Disasters 2007, 31, 477-497. [CrossRef] [PubMed]

9. Föster, S.; Kuhlmann, B.; Lindenschmindt, K.; Bronstert, A. Assessing flood risk for rural detention area. Nat. Hazard Earth Syst. Sci. 2008, 8, 311-322. [CrossRef]

10. Hollis, G.E. The effect of urbanization on floods of different recurrence interval. Water Resour. Res. 1975, 11, 431-435. [CrossRef]

11. UNISDR. Hyogo framework for action 2005-2015: Building the resilience of nations and communities to disasters. In Proceedings of the World Conference on Disaster Reduction, Kobe, Hyogo, Japan, 18-22 January 2005; The United Nations International Strategy for Disaster Reduction: Geneva, Switzerland, 2005; Volume 380. A/CONF. 206/6. Available online: https://www.unisdr.org/files/1037_ hyogoframeworkforactionenglish.pdf (accessed on 1 January 2019).

12. Amangabara, G.T.; Gobo, A.E. Factors that influence the flooding of the Middle and Lower Ntamogba stream catchments, Port Harcourt, Nigeria. J. Environ. Hydrol. 2007, 15, 1-15. Available online: http: //www.hydroweb.com/protect/pubs/jeh/jeh2007/amanga.pdf (accessed on 1 December 2018). 
13. Jha, A.K.; Bloch, R.; Lamond, J. Cities and Flooding: A Guide to Integrated Urban Flood Risk Management for the 21st Century; World Bank Publications: Washington, DC, USA, 2012; Available online: http://siteresources. worldbank.org/INTWBEUROPE/Resources/Brief_Guide_to_Urban_Flood_Risk_Management.pdf (accessed on 1 December 2018).

14. Zúñiga, E.; Magaña, V. Vulnerability and risk to intense rainfall in Mexico: The effect of land use cover change. Investig. Geogr. 2017, 95, 1-18. [CrossRef]

15. Areau-Rangel, O.; Cea, L.; Bonasia, R.; Espinoza-Echavarria, V. Impact of Urban Growth and Changes in Land Use on River Flood Hazard in Villahermosa, Tabasco (Mexico). Water 2019, 11, 304. [CrossRef]

16. Suriya, S.; Mudgai, B. Impact of urbanization on flooding: The Thirusoolam sub watershed-A case study. J. Hydrol. 2012, 412, 210-219. [CrossRef]

17. Smith, K.; Ward, R.C. Floods: Physical Processes and Human Impacts; Wiley: Chichester, UK, 1998; ISBN 0471952486.

18. León, P.A. Natural Disasters; Wm. C. Brown Publishers: Dubuque, IA, USA, 1996; ISBN 9780697254931.

19. Du, J.; Quian, L.; Rui, H.; Zuo, T.; Zheng, D.; Xu, Y.; Xu, C. Assessing the effects of urbanization on annual runoff and flood events using an integrated hydrological modeling system for Qinhuai River basin, China. J. Hydrol. 2012, 464, 127-139. [CrossRef]

20. Sala, M.; Inbar, M. Some hydrology effects of urbanization in Catalan rivers. Catena 1992, 19, $363-378$. [CrossRef]

21. Nations, U. Terminology on Disaster Risk Reduction; United Nations Office for Disaster Risk Reduction, Report, 2009; International Strategy for Disaster Reduction of the United Nations: Geneva, Switzerland, 2009; Available online: https://www.unisdr.org/we/inform/publications/7817 (accessed on January 2019).

22. Li, G.-F.; Xiang, X.-Y.; Tong, Y.-Y.; Wang, H.-M. Impact assessment of urbanization on flood risk in the Yangtze River Delta. Stoch. Environ. Res. Risk Assess. 2013, 27, 1683-1693. [CrossRef]

23. CENAPRED. Impacto Socioeconómico de Los Principales Desastres Ocurridos En La República Mexicana: Serie Impacto Socioeconómico de Los Desastres En México; Secretaría de Gobernación-CENAPRED: Ciudad de México, México, 2017; Volumes 1-15, Available online: http://www.cenapred.unam.mx/PublicacionesWebGobMX/ buscar_buscaSubcategoria?categoria=Series+especiales+\%2F\&subcategoria=Impacto+Socioecon $\%$ $260 a c u t e \% 3$ Bmico + de + los + desastres + en $+\mathrm{M} \% 26$ eacute $\% 3 B x i c o \& p a l a b r a C l a v e=d e+l o s+$ Desastres + en (accessed on 1 January 2019).

24. DesInventar. Sistema de Inventario de Desastres. Available online: https://online.desinventar.org/ (accessed on 1 December 2018).

25. Dirección general de protección civil del municipio de Yautepec de Zaragoza. Plan Municipal de Contingencias Hidrometeorológicas; Dirección General de protección civil del municipio de Yautepec de Zaragoza: Yautepec, Morelos, México, Unpublished manuscript; 2007.

26. Estrada, M. Investigación Hidrológica e Hidrogeológica Para Reducir el Caudal de Escurrimiento en el río Yautepec y Evitar Inundaciones en La Zona Centro de Yautepec, Morelos. Bachelor's Thesis, Universidad Nacional Autónoma de México, Ciudad de México, México, 2005. Available online: http: //oreon.dgbiblio.unam.mx (accessed on 30 November 2018).

27. Zúñiga, E. Análisis del Riesgo Por Inundaciones Como Consecuencia del Desbordamiento del Río Yautepec, Morelos, México. Master's Thesis, Universidad Nacional Autónoma de México, Ciudad de México, México, 2009. Available online: http://oreon.dgbiblio.unam.mx (accessed on 30 October 2018).

28. Stelling, G.S.; Verwey, A. Numerical flood simulation. In Encyclopedia of Hydrological Sciences; John Wiley \& Sons, Ltd.: Hoboken, NJ, USA, 2006. [CrossRef]

29. Bladé, E.; Gómez-Valentín, M.; Dolz, J.; Aragón-Hernández, J.L.; Corestein, G.; Sánchez-Juny, M. Integration of $1 \mathrm{D}$ and 2D finite volume schemes for computations of water flow in natural channels. Adv. Water Resour. 2012, 42, 17-29. [CrossRef]

30. Teng, J.; Jakeman, A.J.; Vaze, J.; Croke, B.F.W.; Dutta, D.; Kim, S. Flood inundation modelling: A review of methods, recent advances and uncertainty analysis. Environ. Modell. Softw. 2017, 90, 201-216. [CrossRef]

31. Knebl, M.R.; Yang, Z.-L.; Hutchison, K.; Maidment, D.R. Regional scale flood modeling using NEXRAD rainfall, GIS, and HEC-HMS/RAS: A case study for the San Antonio River Basin Summer 2002 storm event. J. Environ. Manag. 2005, 75, 325-336. [CrossRef] [PubMed]

32. Hicks, F.E.; Peacock, T. Suitability of HEC-RAS for flood forecasting. Can. Water Resour. J. 2005, 30, $159-174$. [CrossRef] 
33. Yang, J.; Townsend, R.D.; Daneshfar, B. Applying the HEC-RAS model and GIS techniques in river network floodplain delineation. Can. J. Civ. Eng. 2006, 33, 19-28. [CrossRef]

34. Mohammed, J.R.; Qasim, J.M. Comparison of One-Dimensional HEC-RAS with Two-Dimensional ADH for Flow over Trapezoidal Profile Weirs. CJSR 2012, 1, 6. Available online: http://www.cjasr.com/images/ manuscripts/Jun/CJASR-12-07-18.pdf (accessed on 1 January 2019).

35. İ́caga, Y.; Tas, E.; Kilit, M. Flood inundation mapping by GIS and a hydraulic model (HEC RAS): A case study of Akarcay Bolvadin subbasin, in Turkey. Acta Geobalcanica 2016, 2, 111-118. [CrossRef]

36. Khattak, M.S.; Anwar, F.; Saeed, T.U.; Sharif, M.; Sheraz, K.; Ahmed, A. Floodplain mapping using HEC-RAS and ArcGIS: A case study of Kabul River. Arab. J. Sci. Eng. 2016, 41, 1375-1390. Available online: https://link.springer.com/content/pdf/10.1007\%2Fs13369-015-1915-3.pdf (accessed on 1 December 2018). [CrossRef]

37. Thakur, B.; Parajuli, R.; Kalra, A.; Dunn, C.N.; Van Weele, B.; Ahmad, S.; Gupta, R. Coupling HEC-RAS and HEC-HMS in Precipitation Runoff Modelling and Evaluating Flood Plain Inundation Map. World Environ. Water Resour. Congr. 2017, 240-251. [CrossRef]

38. Tenzin, J.; Bhaskar, A.S. Modeling of the Precipitation Induced Flash Flood in Sarpang, Bhutan Using Hec-Ras. Rasayan J. Chem. 2017, 12, 195-202. Available online: http://rasayanjournal.co.in/admin/php/upload/158_pdf. pdf (accessed on 1 January 2019). [CrossRef]

39. Romali, N.S.; Yusop, Z.; Ismail, A.Z. Application of HEC-RAS and Arc GIS for floodplain mapping in Segamat town. Malays. Int. J. 2018, 14, 125-131. [CrossRef]

40. Delgado, C.D.; Isuhuaylas, G.V. Análisis de gran visión de las inundaciones en la cuenca alta del río Lerma: Caso de la subcuenca del río Tejalpa, Estado de México, México. Ing. Hidraul. Mex. 2001, 16, 73-86.

41. Wurl, J.; Martínez, G.; Cynthia, N.; Imaz, L. Caracterización del peligro por inundaciones en el oasis La Purísima, Baja California Sur, México. Investig. Geogr. 2015, 87, 76-87. [CrossRef]

42. Larios-Tlali, H. Riesgo de inundación en la subcuenca del río La Antigua, Veracruz, México. Tecnol. Cienc. Agua 2015, 6, 39-56. Available online: http://www.scielo.org.mx/pdf/tca/v6n3/v6n3a4.pdf (accessed on 1 February 2019).

43. Norman, L.M. Flood hazard awareness and hydrologic modelling at Ambos Nogales, United States-Mexico border. J. Flood Risk Manag. 2010, 3, 151-165. [CrossRef]

44. CONAGUA. Atlas del Agua en México 2015. Available online: http://www.conagua.gob.mx/CONAGUA07/ Publicaciones/Publicaciones/ATLAS2015.pdf (accessed on 1 March 2019).

45. Vide, J. Ingeniería de Ríos [River Engineering], 2nd ed.; Universidad Politécnica de Catalunya: Barcelona, España, 2007; Volume 9, ISBN 978-84-8301-900-9.

46. CONAGUA. Banco Nacional de Datos de Aguas Superficiales (BANDAS). Available online: ftp://ftp.conagua. gob.mx/Bandas/Bases_Datos_Bandas (accessed on 1 February 2019).

47. Escalante, C.; Reyes, L. Técnicas Estadísticas en Hidrología [Statistical Techniques in Hydrology], 1st ed.; Universidad Nacional Autónoma de México, Facultad de Ingeniería: Ciudad de México, México, 2005; ISBN 970-32-0173-3.

48. Rao, A.R.; Hamed, K.H. Flood Frequency Analysis. Ing. Agua 2000, 7, 309. Available online: https: //www.taylorfrancis.com/books/9780429128813 (accessed on 1 December 2018).

49. Chow, V. Hidráulica de Canales Abiertos [Open Channel Hydraulics]; McGraw-Hill: Santafé de Bogotá, Colombia, 1994; ISBN 958-600-228-4.

50. Salas, J.; Delleur, J.; Yevjevich, V.; Lane, W. Applied Modeling of Hydrological Time Series, 4th ed.; Water Resources Pubications: Highlands Ranch, CO, USA, 1998; p. 484. ISBN 978-091833437-4.

51. Chow, V.; Maidment, D.; Mays, L. Applied Hydrology; McGraw-Hill: Singapur, Singapur, 1988; ISBN 0-07-010810-2. Available online: http://ponce.sdsu.edu/Applied_Hydrology_Chow_1988.pdf (accessed on 1 March 2019).

52. INEGI. Conjunto de Datos Vectoriales Topográficos. Carta E14A59. Escala 1:50,000. Available online: http://www.beta.inegi.org.mx/app/buscador/default.html?q=e14a59 (accessed on 1 January 2019).

53. HEC-GeoRAS. Handbook of HecGeoRAS. Available online: http://www.hec.usace.army.mil/software/hecgeoras/ (accessed on 1 February 2019).

54. ArcGis. ArcGis Tutorials. Available online: http://desktop.arcgis.com/es/arcmap/latest/get-started/ introduction/arcgis-tutorials.htm (accessed on February 2019). 
55. INEGI. Modelo Digital de Elevaciones—Continuo de Elevaciones Mexicana 3.0. Available online: http: //www.inegi.org.mx/geo/contenidos/datosrelieve/continental/descarga.aspx (accessed on 1 January 2019).

56. Arcement, G.J.; Schneider, V.R. Guide for Selecting Manning's Roughness Coefficients for Natural Channels and Flood Plains; U.S. Geological Survey: Denver, CO, USA, 1989; ISBN 88-600129. Available online: https://dpw.lacounty.gov/lacfcd/wdr/files/WG/041615/Guide\%20for\%20Selecting\%20n-Value.pdf (accessed on 1 April 2019).

57. Nanía, L.S.; León, A.S.; García, M.H. Hydrologic-hydraulic model for simulating dual drainage and flooding in urban areas: Application to a catchment in the metropolitan area of Chicago. J. Hydrol. Eng. 2014, 20, 04014071. Available online: https://ascelibrary.org/doi/pdf/10.1061/\%28ASCE\%29HE.1943-5584.0001080 (accessed on 1 April 2019). [CrossRef]

58. HEC-RAS. Handbook of HECRAS. Available online: http://www.hec.usace.army.mil/software/hec-ras/ (accessed on 10 January 2017).

59. Chow, V.; Maidment, D.; Mays, L. Hidrología Aplicada; McGraw-Hill: Santafé de Bogotá, Colombia, 1994; ISBN 0-07-010810-2.

60. Hosking, J.R. L-moments: Analysis and estimation of distributions using linear combinations of order statistics. J. Roy. Stat. Soc. Ser. B Methodol. 1990, 52, 105-124. [CrossRef]

61. Ferrer, J. Análisis Estadístico de Caudales de Avenida; Monografías, M26; Centro de Estudios Hidrográficos (CEDEX, MOPT): Madrid, Spain, 1992; p. 42. ISBN 9788477901402.

62. Rosique, L. Análisis del Riesgo Por Inundación En La Ciudad de Villahermosa, Tabasco. Master's Thesis, Universidad Nacional Autónoma de México, Ciudad de México, México, 2010. Available online: http: //oreon.dgbiblio.unam.mx (accessed on 30 November 2018).

63. Campos, A. Introducción a La Hidrología Urbana [Introduction to Urban Hydrology], 1st ed.; Universitaria Potosina: San Luis Potosí, México, 2010; ISBN -970-95118-1-5.

64. Herrero, A.D.; Laín-Huerta, L.; Isidro, M.L. Mapas de Peligrosidad Por Avenidas e Inundaciones: Guía Metodológica Para Su Elaboración; IGME: Madrid, Spain, 2008; No. 1; ISBN 978-84-7840-770-5.

65. Wolfgang, K. Flood risk = Hazard • Values • Vulnerability. Water Int. 2005, 30, 58-68. Available online: http://citeseerx.ist.psu.edu/viewdoc/download?doi=10.1.1.594.999\&rep=rep1\&type=pdf (accessed on 1 December 2018).

66. Merz, B.; Thieken, A.H.; Gocht, M. Flood Risk Mapping at the Local Scale: Concepts and Challenges. In Flood Risk Management in Europe; Springer: Dordrecht, The Netherlands, 2007; pp. 231-251. ISBN 978-1-4020-4199-0. Available online: https://link.springer.com/content/pdf/10.1007\%2F978-1-4020-4200-3_13.pdf (accessed on 1 January 2019).

67. Federal Emergency Management Agency 10 year/50 year flood zones-DFIRM Flood Maps. Available online: https://fema.ideascale.com/a/dtd/10-Year-50-Year-Flood-Zones-DFIRM-Flood-Maps/315482-14692\# idea-tab-comments (accessed on 30 May 2018).

68. Novelo-Casanova, D.A.; Rodríguez-Vangort, F. Flood risk assessment. Case of study: Motozintla de Mendoza, Chiapas, Mexico. Geomat. Nat. Hazards. Risk 2016, 7, 1538-1556. [CrossRef]

69. Wurl, J.; Martínez, G.; Cynthia, N.; Imaz, L. Respuesta hidrológica al cambio climático en regiones áridas: Caso de estudio en los Comondú, Baja California Sur, México. Hidrobiológica 2017, $27,13-22$. Available online: http://www.scielo.org.mx/pdf/hbio/v27n1/0188-8897-hbio-27-01-00013.pdf (accessed on 1 March 2019). [CrossRef]

(C) 2019 by the authors. Licensee MDPI, Basel, Switzerland. This article is an open access article distributed under the terms and conditions of the Creative Commons Attribution (CC BY) license (http://creativecommons.org/licenses/by/4.0/). 